Apidologie, 1982, 13 (4), 383 à 389

\title{
DETERMINATION OF PROTEOLYTIC ACTIVITY IN VARROA JACOBSONI AN ECTOPARASITIC HEMOPHAGOUS MITE OF HONEY BEES (APIS $\boldsymbol{s p . )}$
}

\author{
Naresh C. TEWARSON and Klaus-Dieter JANY \\ Universität Tübingen, Institut für Biologie III \\ Lehrstuhl Entwicklungsphysiologie \\ Auf der Morgenstelle 28, D-7400 Tübingen \\ and Institut für Organische Chemie, Biochemie und Isotopenforschung \\ Universität Stuttgart, Pfaffenwaldring 55, D-7000 Stuttgart, FRG
}

\begin{abstract}
SUMMARY
In previous studies, it was demonstrated through immunotechniques that the Varroa resorbs the ingested hemolymph proteins of honey bees (Apis mellifera) into it's own hemolymph. These same proteins are detectable in the eggs of this parasite (TEWARSON, 1981). To check this undegraded resorption of host proteins, a study of proteolytic activity in Varroa was carried out using homogenates of whole female mites in Tris-HCl-buffer ( $\mathrm{pH} 8.2$ ). Low proteolytic activity could be detected only with the help of very sensitive methods (by using synthetic substrates) and also there were indications that a protease inhibitory factor is present in the Apis hemolymph. A possible explanation of macromolecular uptake of host proteins by Varroa due to an inhibitory factor in the host hemolymph, as well as the low proteolytic activity in the mite, is discussed.
\end{abstract}

\section{INTRODUCTION}

At present the most dreaded disease of honey bees is Varroatosis, which is caused by Varroa jacobsoni, an ectoparasitic mite (RITTER, 1981; de JoNG et al., 1982) feeding on the hemolymph of late larval, pupal and adult honey bees. Immunotechniques have demonstrated that the host proteins (TEWARSON, 1981) and non-host proteins (TEWARSON and ENGELS, 1982) are resorbed without digestion because the proteins of the blood meal could be detected in the hemolymph of the mite and even in their freshly laid eggs. Since minor changes in the antigenic properties were observed after passage through the Varroa gut system, we therefore suppose that a reduced proteolytic activity of the alimentary tract of Varroa enables this hemophagous mite to use the host 
macromolecular proteins. This study was designed to analyse and specify the proteolytic activity present in this mite.

\section{MATERIALS AND METHODS}

The hard cuticular covering and the small size of Varroa make it difficult to remove the midgut by dissection. Therefore, a homogenate of 30 whole mites was made in ice-cold $0.2 \mathrm{M}$ Tris-HC1 buffer $p \mathrm{H}$ 8.2.

The homogenate was centrifuged twice at $11000 \mathrm{~g}$ for $20 \mathrm{~min}$. and the supernatant was used for the enzyme assays.

\section{Photopaper test}

Exposed, wet, photopapers were soaked in $0.2 \mathrm{M}$ Tris- $\mathrm{HCl}$ buffer $p \mathrm{H}$ 8.2. A few drops of Varroa homogenate supernatant were put at the surface of these pretreated photopapers which had been developed black. They were then incubated in a damp chamber inside an incubator at $35^{\circ} \mathrm{C}$ for $1-4$ hours.

\section{Proteolytic activity in polyacrylamide gels}

By this method a direct detection of the protease enzyme is possible.

The enzymes are electrophoretically separated in $10 \%$ polyacrylamide gel for 3 hours at $4^{\circ} \mathrm{C}$ and $30 \mathrm{~mA} / 10$ samples in lycine- $\mathrm{NaOH}-\mathrm{HCl}$ buffer at different $p \mathrm{H}$ values. Afterwards the gel is incubated

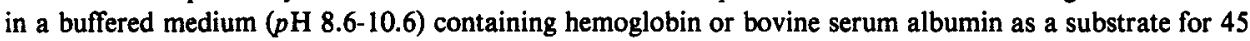
to $360 \mathrm{~min}$. at $37^{\circ} \mathrm{C}$. The gel is fixed, dried, and stained in the normal way with Comassie Blue. The areas of proteolytic degradations are indicated by either pale or non-coloured patches against a blue background (negative staining). This colored background is due to the diffusion of substrate into the gel during incubation. To obtain optimal resolution, variations in $p \mathrm{H}(8.6-10.6)$, substrate concentration (0.2$2 \%)$ and the quantity of the mite's homogenate (3-10 $\mu$ l) are necessary.

\section{Overall proteolytic activity}

In order to specify whether the proteases of Varroa come in exopeptidase or endopeptidase categories, and Hide-Powder-Azure (RINDerknecht et al., 1968). Because Hide-Powder-Azure is an insoluble substrate, the incubation was done under constant shaking. $50 \mu \mathrm{l}$ of the substrate ( $1 \%$ Azocasein $\mathrm{w} / \mathrm{v}$ or Hide-Powder-Azure in $0.2 \mathrm{M}$ Tris- $\mathrm{HCl}$ buffer $p \mathrm{H} \mathrm{8.2)} \mathrm{and} 20 \mu \mathrm{l}$ of the mite homogenate were incubated for $1-3$ hours at $37^{\circ} \mathrm{C}$ for $1 / 2 \mathrm{hr}$. After it was centrifuged, extinction in the supernatant was measured at $366 \mathrm{~nm}$ for Azocasein and at $578 \mathrm{~nm}$ for Hide-Powder-Azure (Serva) (see table 1). Blanks were obtained by adding TCA to the substrate before adding the Varroa homogenate. For qualitative comparision, a protease mixture (Protease K code 33752, Serva) was treated in the same manner.

\section{Specification of the protease of Varroa}

In order to specify wether the proteases of Varroa come in exopeptidase or endopeptidase categories, the following synthetic substrates were used :
A. N-Glutaryl-L-phenylalanin-4-Nitroanilid (GPNA) (ERLANGER et al., 1966).
B. N-Benzoyl-L-arginin-4-Nitroanilid (BAPA) (ERLANGER et al., 1961).
C. L-Alanin-4-Nitroanilid (ANA) (JANY, 1976) (see table 2 and 3).

Substrates were dissolved in $0.2 \mathrm{M}$ Tris- $\mathrm{HCl}$ buffer $p \mathrm{H} 8.2$ to achieve substrate concentrations of 1\%. The mixture of $50 \mu \mathrm{l}$ of substrate solutions (A, B and C) and $20 \mu 1$ of mite homogenate was incubated for $1-3$ hours at $37^{\circ} \mathrm{C}$. An indication of proteolytic breakdown appears in the form of liberated Nitroaniline. The reaction was stopped after 3 hours by adding $2 \mathrm{ml} 8 \%$ TCA to the mixture and stored in the refrigerator for 1 hour. Then it was centrifuged at $3000 \mathrm{~g}$ and the extinction in the supernatant was measured at $405 \mathrm{~nm}$. For comparison, blanks were substituted and treated by the same method described under 3. 
TABL. 1. - Overall proteolytic activity in Varroa jacobsoni

\begin{tabular}{|c|c|c|c|c|}
\hline Enzyme & $\begin{array}{l}\text { Substrate } \\
(50 \mu \mathrm{l})\end{array}$ & $\begin{array}{c}\text { Test-enzyme } \\
\quad(20 \mu \mathrm{l})\end{array}$ & $\begin{array}{c}\text { Varroa- } \\
\text { Homogenate } \\
(20 \mu \mathrm{l})\end{array}$ & $\begin{array}{c}\text { Activity } \\
\% \text { of Test-Enzyme }\end{array}$ \\
\hline $\begin{array}{l}\text { Overall } \\
\text { Proteolytic } \\
\text { Activity }\end{array}$ & Azocasein & $+++(\S)$ & ++ & 39.8 \\
\hline $\begin{array}{l}\text { Overall } \\
\text { Proteolytic } \\
\text { Activity }\end{array}$ & Hide-Powder-Azure & +++ & ++ & 52.5 \\
\hline
\end{tabular}

(§)

+ Average activity $(30-80 \%)$

+++ Very high activity $(80-100 \%)$.

Mixture was prepared in Tris- $\mathrm{HCl}$ Buffer $p \mathrm{H} 8.2$ and incubated for $1-3 \mathrm{~h}$ at $37^{\circ} \mathrm{C}$.

The following substrates were used to determine if the mite protease (exopeptidase) contained carboxypeptidase A- or B-like activity :

1. Hippuryl-lysine for carboxypeptidase B.

2. Hippuryl-phenylalanine for carboxypeptidase $A$.

3. L-Alanin-p-nitroanilide was also used to observe aminopeptidase like activity.

The substrate and enzymes were treated in the same manner as described above. However, extinction for substrate hippuryl-lysine and hippuryl-phenylalanin was checked at $254 \mathrm{~nm}$ and at $405 \mathrm{~nm}$ for L-alanin-p-nitroanilide (see table 3).

4. Protease inhibitor in Apis hemolymph.

$20 \mu \mathrm{l}$ of protease (Serva) and mite homogenate with $50 \mu \mathrm{l}$ of substrate (nitroanilide) were incubated with or without $5 \mu \mathrm{l}$ of $A$ pis hemolymph. Inhibitory activity was detected by comparing the extinction differences at $405 \mathrm{~nm}$ of the individual assays.

TABL. 2. - Enzyme activity of endopeptidases present in Varroa jacobsoni against different artificial substrates.

\begin{tabular}{l|c|c|c|c}
\hline \hline Enzyme & $\begin{array}{c}\text { Substrate } \\
(50 \mu \mathrm{l})\end{array}$ & $\begin{array}{c}\text { Test-enzyme } \\
(20 \mu \mathrm{l})\end{array}$ & $\begin{array}{c}\text { Varroa- } \\
\text { homogenate } \\
(20 \mu \mathrm{l})\end{array}$ & $\begin{array}{c}\text { Activity } \\
\text { \% of Test-Enzyme }\end{array}$ \\
\hline Endopeptidases & $\begin{array}{l}\text { N } \alpha \text { Glutaryl-L-phenyl- } \\
\text { alanin-4 Nitroanilide } \\
\text { (GPNA) } \\
\text { N } \alpha \text { Benzoyl-L-arginin- } \\
\text { 4-Nitroanilide (BAPA) }\end{array}$ & $+++(\S)$ & \pm & 2 \\
\hline \hline
\end{tabular}

(\$)

$\pm \quad$ Very low activity (1-10\%).

+++ Very high activity $(80-100 \%)$.

Mixture was prepared in Tris- $\mathrm{HCl}$ Buffer $p \mathrm{H} 8.2$ and incubated for $1-3 \mathrm{~h}$ at $37^{\circ} \mathrm{C}$. 
TABL. 3. - Identification of exopeptidases in Varroa jacobsoni

\begin{tabular}{l|c|c|c|c}
\hline \hline \multicolumn{1}{c|}{ Enzyme } & $\begin{array}{c}\text { Substrate } \\
(50 \mu \mathrm{l})\end{array}$ & $\begin{array}{c}\text { Test-enzyme } \\
(20 \mu \mathrm{l})\end{array}$ & $\begin{array}{c}\text { Varroa- } \\
\text { Homogenate } \\
(20 \mu \mathrm{l})\end{array}$ & $\begin{array}{c}\text { Activity } \\
\text { \% of Test-Enzyme }\end{array}$ \\
\hline $\begin{array}{l}\text { Carboxypeptidase-B } \\
\text { Carboxypeptidase-A }\end{array}$ & $\begin{array}{c}\text { Hippuryl-lysine } \\
\text { Hippuryl- } \\
\text { phenylalanin }\end{array}$ & $++(\S)$ & - & 0 \\
Aminopeptidase & L-Alanin-4-nitroanilide & +++ & +++ & 98.0 \\
\hline \hline
\end{tabular}

$(\S)$.

- No activity.

$+\quad$ Low activity (10-30\%).

++ Average activity (30-80\%).

+++ Very high activity $(80-100 \%)$

Mixture was preparated in Tris- $\mathrm{HCl}$ Buffer $p \mathrm{H} 8.2$ and incubated for $1-3 \mathrm{~h}$ at $37^{\circ} \mathrm{C}$

The results presented in tables 1-3 are mean values obtained in 4-8 replicates per determination.

\section{RESULTS}

\section{Overall proteolytic activity}

Proteolytic breakdown should cause white zones appear under the drops of mite extract on the tested photopaper, as the gelatin film of the photopaper would be digested by the protease enzyme. However, after prolonged periods of incubation, no visible white zones of proteolytic breakdown appeared. The same was true for the polyacrylamide gels.

After incubation of the separated proteins in the polyacrylamide gels with bovine serum albumin or hemoglobin, no white or pale colored zones were visible. However, in front of protease test mixture, white zones were distinctly visible. It can be concluded from the above experiments that proteolytic activity in the Varroa homogenate is too low to be detected by these tests. On the other hand, with the help of synthetic substrates a very low activity in the mite homogenate could be detected. The color reactions were checked by comparing the extinction differences. These sensitive methods indicated that there are proteases present in Varroa but with suppressed activities (table 1).

\section{Specification of Varroa proteases}

With the help of substrates for endopeptidases (GPNA and BAPA), extremely low extinction differences could be observed, which indicates a negligible amount of endopeptidases, not enough to cleave the long polypeptide chains (table 2).

\section{Identification of exopeptidase of Varroa}

On the other hand, with the substrates for exopeptidases, a fairly strong extinction difference could be observed, indicating the presence of aminopeptidase (exopeptidase) 
in the mite homogenate. The sample with substrate Hippuryl-lysine did not show any extinction difference, whereas the sample with Hippuryl-p-phenylalanin gave a high extinction difference. Hence, the presence of carboxypeptidase-A in Varroa extract is confirmed (table 3).

\section{Protease inhibition by Apis hemolymph}

The samples containing $A$ pis hemolymph show a reduction in protease activity of up to $25 \%$, when compared with the normal activity. This indicates the presence of some kind of protease inibitor in the bee hemolymph which, to some extent, hinders the normal proteolytic breakdown of Apis hemolymph proteins in Varroa.

\section{DISCUSSION}

The presumption that only a low proteolytic activity is present in the mite Varroa jacobsoni was confirmed by these studies. Although, for technical reasons, whole body homogenates were tested, it is suggested that the proteolytic enzymes detected in the mite homogenate belong to the alimentary tract. Cellular lysosomic protease would also not exhibit activity under the $p \mathrm{H}$ regimes used here. By means of special synthetic substrates the main Varroa proteases could be identified as exocarboxypeptidase-A type and aminopeptidase. Such an enzyme equipment of the Varroa gut and the effect of the inhibitory factors of Apis hemolymph on protease activity can effect only a slight reduction in the molecular weight of the ingested proteins, not a complete breakdown of the polypeptides into small oligopeptides. Assuming this to be true, a resorption of indigested macromolecular proteins with nearly unchanged antigenic properties in Varroa has been evaluated using immunotechniques (Tewarson, 1981; Tewarson and Engels, 1982).

There exist other examples among the class Arthropoda which, like Varroa, have been reported to have absorbed and incorporated the host and non-host proteins into the hemolymph, fat bodies and ovary (NoGGE, 1980).

The significance of such a mechanism of macromolecular resorption of host proteins in Varroa has yet to be evaluated. However, incorporation of Apis hemolymph proteins into the eggs of this mite (probably as vitellogenins) shows a high degree of parasitic adaptation. Perhaps this particular type of vitellogenesis enables the adult female mite to produce more eggs within the short reproductive period which she spends in the capped Apis brood cells.

\section{ACKNOWLEDGEMENTS}

We are greatfull to Profs. RutTner and Koeniger, Bee Research Institute, Oberursel, for making the Varroa mites available for this study. Thanks are due to Prof. W. ENGELs for suggestions 
and comments. N.C. Tewarson, who is on leave from Ewing Christian College, University of Allahabad, India, extends his thanks to Ökumenisches Studienwerk, Bochum, for presenting a doctoral scholarship.

Received for publication in August 1982.

\author{
RÉSUMÉ \\ DETTERMINATION DE L'ACTIVITÉ PROTÉOLYTIQUE CHEZ L'ACARIEN \\ VARROA JACOBSONI, ECTOPARASITE HÉMATOPHAGE DE L'ABEILLE (Apis sp.)
}

On a étudié de façon approfondie l'activité protéolytique de Varroa jacobsoni. Des recherches antérieures ont montré que les protéines de l'hôte, c'est-à-dire les protéines de l'hémolymphe d'Apis mellifica, sont résorbées sans être digérées par l'acarien. Il en est de même pour des protéines étrangères offertes expérimentalement, telles que le mélange albumine-sérum de bøuf.

Puisqu'il est difficile d'obtenir une préparation propre du tractus intestinal de Varroa, on a travaillé avec des homogénats totaux de 30 femelles chacun. Les tests protéasiques suivants ont été effectués en conditions in vitro, conditions optimales pour les protéases intestinales des Arthropodes : 1) test avec du papier photographique; 2) incubation avec substrat de protéases natives séparées auparavant sur gel de polyacrylamide; ces deux méthodes ne permettent pratiquement pas de mettre en évidence une activité protéolytique globale; 3 ) incubation avec substrats artificiels et colorants, à savoir azocaséine et Hide-Powder-Azure; les modifications de l'extinction permettent également de déterminer une activité protéasique faible par rapport aux enzymes témoins (Tabl. 1). Pour déterminer les types de protéases présents chez Varroa on a utilisé les nitroanilides (GNPA, BAPA et ANA) comme substrats synthétiques. Après l'incubation in vitro la nitroaniline libérée est déterminée photométriquement. On peut affirmer que l'activité protéolytique due aux endopeptidases existe à peine chez Varroa et qu'elle est par contre entièrement due aux exopeptidases; celles-ci ont été identifiées, à l'aide de la lysine-hippuryl ou la phénylalanine-hippuryl comme substrat, comme étant exclusivement des carbopeptidases de type A. Avec le nitroanilide-aniline on a obtenu de plus une activité des aminopeptidases (Tabl. 3).

On a observé en outre une inhibition partielle de l'activité peptidasique in vitro vis-à-vis du substrat nitroanilide-acides aminés due à un facteur encore inconnu présent dans l'hémolymphe d'abeille. Il se peut que ce facteur inhibe particulièrement les endopeptidases de sorte que les protéines à chaine longue de l'hôte ne sont pas dégradées en oligopeptides. Ceux-ci n'ont été mis en évidence ni par les tests de protéolyse, ni par les travaux immunologiques antérieurs, où ils auraient dû être reconnus d'après les propriétés antigéniques modifiées.

La discussion porte sur le point suivant : dans quelle mesure l'inhibition des protéases par le sang de l'hôte et d'autre part la résorption des protéines macromoléculaires provenant du repas de sang et rendue possible par une activité protéolytique globale réduite peuvent représenter une adaptation particulière de cet acarien sténophage aux conditions limitées de reproduction dans des cellules de couvain d'abeille operculées.

\title{
ZUSAMMENFASSUNG
}

\section{BESTIMMUNG DER PROTEOLYTISCHEN AKTIVITÄT BEI DER MILBE VARROA JACOBSONI, EIN EKTOPARASIT UND BLUTSAUGER DER HONIGBIENE ( $A$ pis sp.)}

In einer ausführlichen Studie wurde die in Varroa jacobsoni vorkommende proteolytische Aktivität proteinchemisch untersucht. Anlass waren früher erhaltene Befunde, nach denen Proteine des Wirts, nämlich Haemolymph-Proteine von Apis mellifera, unverdaut von der Milbe resorbiert werden. Das 
gleiche gilt für experimentell angebotene Fremd-Proteine wie Rinder Serum-Albumin. Apis-Proteine werden' auch in die Varroa-Eier eingebaut.

$\mathrm{Da}$ eine saubere Präparation des Milben-Darmtraktes schwierig ist, wurde hier mit TotalHomogenaten von je 30 adulten Milben- $\$ q$ gearbeitet. Die folgenden Proteasen-Tests wurden unter in vitro-Bedingungen, die für Darm-Proteasen von Arthropoden optimal sind, durchgeführt : PhotopapierTest; Substrat-Inkubation nativer, zuvor auf Polyacrylamidgel aufgetrennter Proteasen; mit diesen beiden Methoden liess sich praktisch keine proteolytische Gesamt-Aktivität nachweisen. Inkubation mit Farbstoffgekoppelten künstlichen Substraten, nämlich Azocasein und Hide-Powder-Azure; aus den Extinktionsänderungen hann ebenfalls eine im Vetgleich zu Kontroll-Enzymen niedrige Proteasen-Aktivität bestimmt werden (Tabl. 1). Zur Bestimmung der in Varroa vorliegenden Protease-Typen wurden als synthtische Substrate Nitroanilide (GPNA, BAPA und ANA) verwendet; nach in vitro-Inkubation wurde hier das freigesetzte Nitroanilin photometrisch bestimmt. Als Ergebnis ist festzustellen, dass in Varroa kaum Endopeptidase-Aktivität vorkommt (Tab. 2), jedoch durchaus Exopeptidasen; diese wurden mit HippurylLysin bzw.-Phenylalanin als Substrat als ausschliesslich Carboxypeptidase A-Typ erkannt. Mit AlaninNitroanilin wurde ausserdem eine schwächere Aktivität von Aminopeptidasen ermittelt (Tab. 3).

Weitherhin wurde eine partielle Hemmung der in vitro-Peptidasen-Aktivität gegenüber AminosäureNitroanilid als Substrat durch einen noch unbekannten Faktor in der Apis-Haemolymphe gefunden. Vielleicht hemmt dieser Faktor besonders die Endopeptidasen, so dass die langkettigen Wirts-Proteine nicht zu Oligopeptiden abgebaut werden. Solche wurden weder in den Proteolyse-Tests festgestellt noch immunologisch in den früheren Arbeiten nachgewiesen, wo sie aufgrund veränderter Antigen-Eigenschaften hätten erkannt werden müssen.

Es wird diskutiert, inwieweit einmal die Proteasen-Hemmung durch Wirtsblut, zum anderen die aufgrund ingesamt geringer proteolytischer Aktivität mögliche Resorption von makromolekularem Protein aus der Blutmahlzeit eine besondere Anpassung dieser stenophagen Milbe an die begrenzten Fortpflanzungsmöglichkeiten nur in verdeckelten Bienenbrutzellen darstellen kann.

\section{REFERENCES}

Dahlman B., Jany K.-D. and Pfleiderer G., 1978. - The midgut endopeptidases of honey bee (Apis mellifica) : Comparision of the enzyme in different ontogenic stages. Insect Biochem, 8, 203-211.

ERLANGer B. F., Kokowsky N. and CoHeN W., 1961. - The preparation and properties of two new chromogenic substrates of trypsin. Arch. Biochem. Biophys, 95, 271-278.

ERlanger B. F., Edel F. and CoOper A. C., 1966. - The reaction of chymotrypsin on two new chromogenic substrates. Arch. Biochem. Biophys, 115, 206-210.

JANY K.-D., 1976. - Studies on the digestive enzymes of the stomachless bonefish, Carassius auratus gibelio (Bloch) : Endopeptidases. Comp. Biochem. Physiol., 53 B, 31-38.

Jong D. de, MORSE R. A., EickworT G. C., 1982. - Mite pests of honey bees. Ann. Rev. Entomol, 27, 229-252.

NoGGE G., 1980. - On the absorption of undigested albumin by the tsetse fly, (Glossina m. morsitans Westwood. Verh. Disch. Zool. Ges. Berlin, 310.

Rinderknecht H., Geokas M. C., Silverman P. and Haverback B. J., 1968. - A new ultrasensitive method for the determination of proteolytic activity. Clin. Chim. Acta, 21, 197-303.

Ritter W., 1981. - Varroatosis, a new disease of the bee Apis mellifera. Animal Res. Developm., 14, 130 133.

TEwarson N. C., 1981. - Immunologische Untersuchungen über die Rolle von Hämolymph-Proteinen der Honigbiene für die Ernährung und Fortpflanzung von Varroa jacobsoni. In: F. Ruttner (ed.), Diagnose und Therapie der Varroatose, p. 39-47. Apimondia Verlag, Bukarest.

TEWARSON N. C. and ENGEls W., 1982. - Undigested uptake of non-host proteins by Varroa jacobsoni (Ms. submitted in J. Apicult. Res.). 